from Copyright Agency Limited. For information

about such licences contact Copyright Agency

Limited on (02) $93947600(\mathrm{ph})$ or (02) 93947601

(fax)

\title{
The Early History of Glastonbury Abbey: A Hypothesis Regarding the 'British Charter'
}

\author{
Martin Grimmer
}

\begin{abstract}
The so-called 'British charter' of Glastonbury Abbey in Somerset, contained in William of Malmesbury's De antiquitate Glastonie ecclesie of c.1129, records a grant made in $\mathrm{AD} 601$ by an unnamed king of British Dumnonia of land at 'Ineswitrin'. As William regarded this to be the British Celtic name for - Glastonbury, the charter has been used to proclaim a pre-Saxon foundation for the Abbey. When the characteristics of the charter are considered, in particular the use of a scribal attestation, it appears however that it is West Saxon in form and should be dated to the later seventh century when Somerset was within West Saxon control. The charter cannot therefore substantiate the Abbey's existence before this time, though it does imply some level of cooperation between the West Saxon Church and the kingdom of Dumnonia.
\end{abstract}

In the literature on early Anglo-Saxon Christianity it is currently popular to examine possible points of continuity with the Romano-British past. ${ }^{1}$ For the kingdom of Wessex, the focus of this paper, it is often asserted that the West Saxon church, particularly in the west of the realm, took over a pre-existing British ecclesiastical structure. In this sense, British monasteries and other ecclesiastical sites are thought to have provided a foundation for West Saxon establishments, with the British Celtic communities in some fashion metamorphosing into West Saxon Roman houses. While it is not usually made clear what the putative British legacy might actually have been, it is nonetheless common to encounter historians who assert such things as: 'the Saxon church in the region ... must have been based almost entirely on a sub-Roman

' In this paper, the term 'British' will always refer to Celtic Britons, and never to the English or Anglo-Saxons. 
foundation', ${ }^{2}$ or 'there seems little doubt that the structure of the church in western Wessex owed much to its British inheritance'. ${ }^{3}$

One of the most well-known monasteries that has been used as an example of such a metamorphosis is Glastonbury Abbey, which became one of the wealthiest of the West Saxon houses. Glastonbury has long been associated with early, pre-Saxon Christianity in Britain, with connections made to Joseph of Arimathea, ${ }^{4}$ to saints such as Patrick ${ }^{5}$ and Gildas, ${ }^{6}$ and to secular figures such as Arthur and Guinevere. ${ }^{7}$ Most of the legends of a pre-Saxon foundation for

2 Patrick Hase, 'The church in the Wessex heartlands', The Medieval Landscape of Wessex, eds Michael Aston and Carenza Lewis (Oxford: Oxbow Monograph 46, 1994), pp. 47-81 (p. 51).

3 Barbara Yorke, Wessex in the Early Middle Ages (London: Leicester University Press, 1995), p. 181.

4 A list of the saints' relics claimed to be in the possession of Glastonbury is provided by John of Glastonbury in his Cronica sive antiquitates Glastoniensis ecclesie, Ch. 5 (ed. James P. Carley, The Chronicle of Glastonbury Abbey: An Edition, Translation and Study of John of Glastonbury's Cronica sive Antiquitates Glastoniensis Ecclesie, [Woodbridge: Boydell Press, 1985], pp. 17-21), written in the 1340s. The first official recognition of the role of Joseph of Arimathea, supposed to have arrived at Glastonbury in 63AD, is not until John of Glastonbury's Cronica (Carley, Chronicle of Glastonbury Abbey, pp. xxv$\mathrm{xxx}, \mathrm{li}$ ). Joseph's foundation is described in the Introduction and Ch. 19.

3 St Patrick's association with Glastonbury is complex. He was the subject of the well-known forged charter that was created sometime after the Glastonbury fire of 1184 , included in Adam of Domerham's Historia de rebus gestis Glastoniensibus, J.19-22 (ed. T. Hearne, 2 vols., Oxford, 1727), written c.1290. See Carley, Chronicle of Glastonbury Abbey, pp. xxxvi-ii, and Antonia Gransden, 'The gtowth of the Glastonbury traditions and legends in the twelfth century', Journal of Ecclesiastical History, 27 (1976), 337-58, (p. 340). The earliest recorded association of St Patrick with Glastonbury is in the late tenth-century Life of St Dunstan by 'B', Ch. 5, in which Patrick is 'said to rest there happily with the Lord'. See English Historical Documents c. 500-1042, ed. Dorothy Whitelock (London: Eyre and Spottiswoode, 1955), no. 234, p. 826 (henceforth EHD). On St Patrick, see also the collection recently edited by David Dumville, Saint Patrick, A.D. 493-1993 (Woodbridge: Boydell Press, 1993).

- Gildas's association with Glastonbury was cemented by Caradoc of Llancarfan in his Life of Gildas, written for Glastonbury c.1140 (see Carley, Chronicle of Glastonbury Abbey, p. 273, n.14).

7 Accounts of the exhumation of Arthur and Guinevere are found in Gerald of Wales's De principis instructione 1.20 (c.1192) and his Speculum ecclesie II.8-10 (c.1217). See The Journey Through Wales/The Description of Wales, ed. Lewis Thorpe (Harmondsworth: Penguin, 1978), pp. 281-88.

Parergon 20.2 (2003) 
Glastonbury are, however, without a documentary basis. ${ }^{8}$ The earliest actual documentary evidence that derives from the Glastonbury archives that can be used to argue for a pre-Saxon origin and for British continuity at the site is a charter which appears to date from the early seventh century. It is the aim of this paper to discuss the authenticity and implications of this so-called 'British charter'.

The charter begins an account of grants to Glastonbury contained in William of Malmesbury's De antiquitate Glastonie ecclesie, commissioned by the abbey c.1129. ${ }^{9}$ William's task in writing the De antiquitate Glastonie was to produce a document which validated Glastonbury's antiquity, as well as to counter a claim made by Osbern of Canterbury that Glastonbury's foundation only occurred in the mid-tenth century. ${ }^{10}$ The De antiquitate Glastonie does not survive in the original; the earliest version (MS T) is from the mid-thirteenth century and incorporates a number of later interpolations. ${ }^{11}$ However, the charter was also included, with some modification, in Version C of the Gesta regum Anglorum, compiled by William after he had written the De antiquitate Glastonie, most likely for presentation to Glastonbury. ${ }^{12}$ Thus, its place in the De antiquitate Glastonie can safely be ascribed to William. ${ }^{13}$

The British charter, drawn up by a Bishop Mauuron, records a grant to the 'old church' made by an unnamed king of Dumnonia of five hides at Ineswitrin, ${ }^{14}$ at the request of Abbot Worgret. William records the grant as follows:

B Sarah Foot, 'Glastonbury's early abbots', The Archaeology and History of Glastonbury Abbey, ed. Lesley Abrams \& James P. Carley (Woodbridge: Boydell Press, 1991), pp. 16389, (p. 168, n. 27).

9 All references to this work (henceforth AG) will be cited by chapter and page numbers from Iohn Scott, The Early History of Glastonbury: An Edition, Translation and Study of William of Malmesbury's 'De Antiquitate Glastonie Ecclesie' (Woodbridge, Suffolk: Boydell Press, 1981).

10 Osbern's Vita Sancti Dunstani, in Memorials of St. Dunstan, ed. W. Stubbs, RS 63 (London, 1874), Ch. 19, pp. 92-94. Osbern's claim was specifically refuted in AG 55, pp. 115-17. See Foot, 'Glastonbury's early abbots', pp. 163, 179.

1 Scott, The Early History of Glastonbury, pp. 34-39.

12 All references to this work (hence GR) will be cited by book, chapter and page number from William of Malmesbury, Gesta Regum Anglorum: The History of the English Kings, Vol. I, ed. and trans. R. A. B. Mynors, Rodney M. Thomson and Michael Winterbottom, (London: Clarendon Press, 1998). See GR 1.27-28, pp. 812-13, for the charter, and pp. xvii-xx for comment on Version C.

13 Foot, 'Glastonbury's early abbots', p. 167, n. 22.

14 Except within direct quotations, the form Ineswitrin will be used throughout this paper.

Parergon 20.2 (2003) 
On the estate of Ynswitrin, given to Glastonbury at the time the English were converted to the faith.

In $601 \mathrm{AD}$ the King of Dumnonia ${ }^{15}$ granted five cassates on the estate called Inesuuitrin to the old church on the petition of Abbot Worgret. I, Bishop Mauuron wrote this charter. I, Worgret, abbot of that place, have subscribed. The age of the document prevents us knowing who the king was, yet it can be presumed that he was British because he referred to Glastonbury in his own tongue as Yneswitrin which, as we know, was the British name. But Abbot Worgret, whose name smacks of British barbarism, was succeeded by Lademund and he by Bregored. The dates of their rule are obscure but their names and ranks can clearly be seen in a painting to be found near the altar in the greater church. Berthwald succeeded Bregored. ${ }^{16}$

On the face of it, this charter is extremely significant in that it documents a donation by a British king to what became a Saxon house; William clearly states that Ineswitrin was the British name for Glastonbury. Given that William dated the charter to 601, this would proclaim a pre-Saxon foundation for Glastonbury, and indeed, the actual survival of the charter, if it is genuinely British, implies

is Scott, Early History of Glastonbury, p. 89, erroneously translates Domnonie as Devon, rather than Dumnonia. Dumnonia encompassed Comwall, Devon and parts of Somerset. Refer to GR 1.100, pp. 146-47, and the comment in Rodney M. Thomson and Michael Winterbottom, William of Malmesbury, Gesta Regum Anglonum: The History of the English Kings, Vol. II, General Introduction and Commentary (London: Clarendon Press, 1999), p. 405.

16 'De terra Ynswitrin data Glastonie tempore Anglorum ad fidem conversorum. Anno Dominice incarnacionis sexcentesimo primo rex Domnonie terram, que appellatur Inesuuitrin (MS H: Yneswitrin), ad ecclesiam vetustam concessit ob peticionem Worgret abbatis in quinque cassatis (superscript: id est hidis). Ego Mauuron episcopus hanc cartam scripsi. Ego Worgret euisdem loci abbas subscripsi. Quis iste rex fuerit scedule vetustas negat scire, verumptamen quod Britannus fuerit hinc presumi potest, quod Glastoniam (MS $\mathrm{H}$ : Glastonia) lingua sua Yneswitrin appellavit, sic enim eam Britannice vocari apud eos constat. Worgret autem abbati, cuius nomen Britannicam barbariem redolet, successit Lademund et ei Bregoretd. / Prelacionis eorum tempora sunt in obscuro set nomina illorum et dignitates in maiori ecclesia prodente secus altare pictura sunt in propatulo. Bregoredo sucessit Berthwald' (AG 35, pp. 88-89).

In AG 69, pp. 140-1, William summarises this grant as follows: 'The King of Dumnonia gave 5 hides of land known as Yneswitherim' ('rex Domnonie dedit terram apellatam Yneswitherim $v$ hidas').

In GR I.27-8, pp. 812-3, Worgret is rendered as Worgrez; Mauuron as Maworn; Inesuuitrin as Ineswitrin. Scoth, Early History of Glastonbury, p. 197, n. 78, states that it is safe to assume that William himself made these changes. 
some level of continuity between British and Saxon communities; the record would likely not have endured if there was a break in monastic life. ${ }^{17}$ However, the interpretation of the charter is not so straightforward, and opinion on its value is divided ${ }^{18}$ While it does not appear to contain any explicitly forged elements, it could certainly have been manufactured to lend weight to the claim for Glastonbury's antiquity. ${ }^{19}$ There is no doubt that many aspects of the charter are problematic and stand in the way of it automatically being used as evidence for Glastonbury being a pre-Saxon foundation. ${ }^{20}$

To begin with, the genuine date of the charter is difficult to determine. William provided the date of 601 , which he probably transcribed from the document that he was working from - William's exactitude as an historian provides some consolation here. But it is highly improbable that such a date would have been on the original; the anno domini system did not enjoy widespread use in Britain till after the time of Bede, and there is little evidence that it was used in Anglo- Saxon charters before the eighth century. ${ }^{21}$ Rather, early Anglo-Saxon charters

17 Heather Edwards, The Charters of the Early West Saxon Kingdom (Oxford: British Archaeological Reports 198, 1988), p. 65.

18 Edwards, ibid., in her detailed examination of the charters of early Wessex, has assessed the charter as probably genuine. While some of the details are puzzling, she can see no motive for forgery: the persons are otherwise unknown and the transaction lends no support to any particular tradition of an ancient saint. Foot, 'Glastonbury's early abbots', p. 167, n. 21 , on the other hand, sees 'no grounds for placing any reliance on this "document"'; she considers Glastonbury to have been a Saxon foundation of the late seventh century. Similarly, David Dumville, personal communication, cited in James P. Carley, Glastonbury Abbcy: The Holy House at the End of the Moors Adventurous (London: Guild Publishing, 1988), p. 2, n. 4, regards the charter as a 'rank forgery'. Michael Costen, The Origins of Somerset (Manchester: Manchester University Press, 1992), p. 78, appears to concur. Lesley Abrams, Anglo-Saxon Glastonbury: Church and Endowment (Woodbridge, Suffolk: Boydell Press, 1996), p. 124, n. 1, has most recently assessed the charter as 'unconvincing'.

19 Rosamond Faith, The English Peasantry and the Growth of Lordship (London: Leicester University Press, 1997), p. 24.

20 There is no suggestion that the record in the De antiquitate Glastonie represents the actual foundation charter of Glastonbury, even though it heads William's list of grants. The grant was to the 'old church', implying that some establishment must have already been there. See Abrams, Anglo-Saxon Glastonbury, pp. 123-31.

21 Edwards, Early West Saxon Charters, p. 11. Kenneth Harrison, 'The annus domini in some early charters', Journal of the Society of Archivists, 4 (1973), 551-57, argues that Wilfrid of York may have introduced the use of anno domini dating for charters after the Symod of Whitby in 664. Even though his examples are principally Mercian, his claim does not in any event help to substantiate the much earlier 601 date of the British charter.

Parergon 20.2 (2003) 
were typically dated by indictional year. ${ }^{22}$ So, if William was transcribing the date as he found it, we must assume that it was interpolated at some later time. William obviously believed the charter to be representative of Glastonbury's antiquity; in his account in the Gesta regum, he thought it important to comment that Glastonbury must be an ancient foundation as 'even then [it] was called Old Church' ${ }^{23}$ But this does not provide any precision in dating. In the De antiquitate Glastonie account, William stated that the document was of an age such that the name of the king was not identifiable. ${ }^{24}$ This may be taken as evidence that the charter was very old - William was otherwise quite accomplished at deciphering documents - but not as a guide to its exact vintage. And indeed, we need to remember William's task of establishing the antiquity of Glastonbury Abbey; he may have been moved to err on the side of great age. In any event, we are left with the conclusion that there is no security in the 601 date.

A further problem concerning the British charter is that certain features do not appear to be British, but instead are Anglo-Saxon. A detail which would certainly not have appeared on a British original is the description of the amount of land granted as five cassates or hides. This is an Anglo-Saxon land unit that would obviously not have been used by the British prior to Saxon conquest. ${ }^{25}$ Thus, if the charter is British, this detail must have been altered. The character of the attestations also does not appear to be British. William records the

22 Pierre Chaplais, 'Some early Anglo-Saxon diplomas on single sheets: originals or copies?', Prisca Munimenta: Studies in Archival and Administrative History, ed. Felicity Ranger (London: University of London Press, 1973), pp. 63-87, (p. 73); Patrick Wormald, Bede and the Conversion of England: the Charter Evidence (Jamow: Parish of Yarrow, 1984), pp. 4-5. See also C. R. Cheney, Handbook of Dates for Students of English History (London: Royal Historical Society, 1970), pp. 2-3.

23 GR I.28, p. 813. The statement in the AG 35 chapter heading that the grant was given 'at the time the English were converted to the faith' is also indicative of William's belief in the charter's antiquity.

24 It would be reasonable to presume by this that William meant that the poor condition of the document caused the king's name to be illegible. See Edwards, Early West Saxon Charters, p. 64.

2s In the Liber Landavensis - the so-called 'Llandaff Charters' - by way of comparison, land was measured in terms of either unciae or modii. There were 12 modii to the uncia, the latter approximating 500 acres. See Wendy Davies, 'Unciae: land measurement in the Liber Landavensis', Agricultural History Review, 21 (1973), 111-21, (pp. 112 \& 118), and her An Early Welsh Microcosm: Studies in the Llandaff Charters (London: Royal Historical Society, 1978), p. 33.

Parergon 20.2 (2003) 
attestations as follows: 'Ego Mauuron episcopus hanc cartam scripsi', ${ }^{26}$ and 'Ego Worgret euisdem loci abbas subscripsi'. It has been claimed that this format is not consistent with the 'British Celtic' convention of charter writing - as far as one can tell since the surviving evidence is somewhat later. ${ }^{27}$ But the point is probably sound that the attestations are not recognisably British; the form William records for Abbot Worgret's attestation, for example, is in fact the usual seventhcentury form for the attestation of a literate churchman in West Saxon charters. ${ }^{28}$ So again, if the charter was originally British, we are required to presume some alteration, perhaps to make it more palatable within an Anglo-Saxon milieu. ${ }^{29}$

These actual attestations, particularly the one by Mauuron, warrant closer examination. The form of Mauuron's attestation - 'Ego Mauuron episcopus hanc cartam scripsi' - is of particular relevance to the authenticity of the charter. This attestation format - which is called a scribal attestation - is consistent with a

25 'Mauuron ... scripsi' is rendered 'Mawom ... conscripsi' in GR I.27, p. 813.

27 For instance, in the collection of charters in the Liber Landavensis the attestations appear in the form: 'testes sunt ...' followed by a list of names. See Davies, Early Welsh Microcosm, pp. 7-8, and Wendy Davies, 'The Latin charter-tradition in western Britain, Brittany and Ireland in the early medieval period', Ireland in Early Medieval Europe: Studies in Memory of Kathleen Hughes, ed. Dorothy Whitelock, Rosamond McKitterick, and David Dumville (Cambridge: Cambridge University Press, 1982), pp. 258-80, (pp. 263-64, 266). Davies, 'Latin charter-tradition in western Britain', pp. 259-61, catalogues 203 complete Latin charters surviving from the Celtic areas of early medieval Europe, including 149 in the Liber Landavensis. The usefulness of the Llandaff Charters could, of course, be contested; they are a twelfth-century compilation which has been criticised as being too late to be representative of British practice before the ninth century. See, for example, Ken Dark, Civitas to Kingdom: British Political Continuity 300-800 (Leicester: Leicester University Press, 1994), pp. 140-48; Patrick Sims-Williams, 'Review of W. Davies, "The Llandaff Charters"', Journal of Ecclesiastical History, 33 (1982), 124-29.

28 As Edwards herself points out in Early West Saxon Charters, p. 108. Throughout the De antiquitate Glastonie, the attestations William records are broadly consistent with AngloSaxon cartulary versions.

29 That William recorded the attestations in the first person suggests that he was transcribing the wording as he read it. The use of the first person is, in addition, a further indication that the charter is not characteristically British. Latin charters from Celtic areas were typically written in the third person, using a past tense, rather than in the first person (see Davies, 'Latin charter-tradition', p. 262). 
very small group of late seventh- and early eighth-century West Saxon charters: four out of approximately 35 which survive pre- $725 .^{30}$

The scribal attestation format appears to have been peculiarly Continental in origin. ${ }^{31}$ For instance, it was usual for the scribe of a sixth and seventh-century Italian private deed to be identified (within a 'completio' clause) and to subscribe it as such, and this practice was continued amongst the Lombards, Vandals and Franks. ${ }^{32}$ It is probable, therefore, that the introduction of the scribal attestation

30 The four principal charters and attestations are:

Shaftesbury: S1164/BCS107, pp. 229-34, c.670-675,-'Ego Uuimbertus presbiter qui hanc cartulam rogante supra effato abbate scripsi et subscripsi'.

Glastonbury: S236/BCS61, pp. 11-15, c.681, 'Ego Haedde epsicopus kartulam scripsi'.

Glastonbury: S237/BCS62, pp. 15-17, c.682, 'Ego Aldhelm hanc scedulam scripsi et subscripsi'.

Abingdon: S239/BCS100, pp. 172-4, c.705-26, 'Ego Winberctus hanc cartam scripsi et subscripsi'.

(Charters are cited by Sawyer reference number, Birch Cartularium Saxonicum edition where assigned, and page numbers from Edwards, Early West Saxon Charters). Edwards, Early West Saxon Charters, pp. 314-15, rates S1164 as being almost entirely authentic in its appearance, and rates $\mathrm{S} 236$ and $\$ 237$, as containing a preponderance of authentic elements. S239, on the other hand, is probably spurious as it stands, but the actual scribal attestation may well have an authentic basis. See Edwards, Early West Saxon Charters, p. 231; Simon Keynes, An Atlas of Attestations in Anglo-Saxon Charters, c.670-1066 (Cambridge: Dept. Anglo-Saxon, Norse and Celtic, 1998), p. 6. S243/B103, pp. 105-07, c. 701 , in the Malmesbury archive, contains an attestation that also indicates authorship, though not in the same format as the previous four, namely: 'Ego Winberhtus hanc donationem dictans subscripsi'. $\mathbf{S 2 3 6}$ is also recorded by William with the scribal attestation (AG 38, pp. 90-91). William notes another scribal attestation, 'Ego Aldelmus hanc scedularn scripsi' (AG 40, pp. 94-95), but the cartulary version only records the more common 'Ego ... subscripsi' (S248/B113, pp. 27-33).

31 Susan Kelly, 'Anglo-Saxon lay society and the written word', The Uses of Literacy in Early Medieval Europe, ed. Rosamond McKitterick (Cambridge: Cambridge University Press, 1990), pp. 36-62, (p. 42); Pierre Chaplais, 'Who introduced charters into England? The case for Augustine', Prisca Munimenta, ed. Ranger, pp. 88-107, (pp. 100-01); Wormald, Bede and the Conversion of England, p. 13.

32 Chaplais, 'Anglo-Saxon diplomas on single sheets', p. 77; Piere Chaplais, 'The origin and authenticity of the royal Anglo-Saxon diploma', Prisca Munimenta, ed. Ranger, pp. 28-42, (pp. 30-31); Edwards, Early West Saxon Charters, pp. 12-3; H. P. R. Finberg, 'Ynyswitrin', in his Lucerna: Studies of Some Problems in the Early History of England (London: MacMillan, 1964), pp. 83-94, (p. 87). By way of comparison, indications of authorship in Rome and Ravenna followed the form 'scribendum ... dictavi'; in Lombard charters, 'scribendum ... rogavi' (see Chaplais, 'Origin and authenticity of the royal diploma', p. 30).

Parergon 20.2 (2003) 
format into Wessex was by one of the Frankish bishops to the West Saxons, ${ }^{33}$ with Leuthere (c.670-76) being the most likely candidate. His dates correspond with those of the relevant charters with scribal attestations, and he appears as the second witness on the earliest. ${ }^{34}$

If this is the case, it appears that Leuthere instructed a small circle of clergymen in the use of the scribal attestation. Three scribal names appear on the charters: Haedde, who became bishop of the West Saxons (c.676-705); Wimberht, a priest who may have become abbot of Nursling (Hants.), and Aldhelm, abbot of Malmesbury (c.673-705) and bishop of Sherbome (c.7059). ${ }^{35}$ These three clergymen and Leuthere certainly seem to have known each

33 This particular Frankish connection is suggested by Edwards, Early West Saxon Charters, p. 13.

34 S1164/B107, pp. 229-34. For the dates of the episcopate of Leuthere, see the-Anglo Saxon Chronicle 670, 676: The Anglo-Saxon Chronicles (New Edition), trans. \& ed. M. Swanton (London: Phoenix Press, 2000). All references to the Chronicle (hence ASC) will be made from this edition. For episcopal succession in seventh-century Wessex, see Bede, Historia ecclesiastica gentis Anglonum, III.7. All references to the Historia ecclesiastica (hence $\mathrm{HE}$ ) will be cited by book and chapter number from Bede's Ecclesiastical History of the English People, ed. and trans. Bertram Colgrave and R. A. B. Mynors (Oxford: Oxford Medieval Texts, 1969).

35 For Haedde, see ASC 676, HE V.18. For Wimberht, see Michael Lapidge and Michael Herren, Aldhelm: The Prose Works (Cambridge: D.S. Brewer, 1979), p. 151. For Aldhelm, see Lapidge and Herren, Aldhelm: Prose Works, pp. 8-10, ASC 709, HE V.18. The date of the commencement of Aldhelm's abbacy at Malmesbury is open to debate. William of Malmesbury in his Gesta pontificum Anglorum stated that Aldhelm died in his thirty-fourth year after being appointed abbot, which gives a date of $675 / 6$ (Willelmi Malmesbiriensis Monachi: De Gestis Pontificum Anglorum, ed. N. E. S. A. Hamilton, RS 52, London, 1870, V.231, pp. 385). References to the Gesta pontificum (hence GP), are cited by book, chapter, and page numbers from Hamilton's edition. Lapidge and Herren, Aldhelm: Prose Works, pp. 9, 14, 140-43, linked the beginning of his abbacy with the date of the letter to Geraint which they argue, as will be seen, was sent soon after the Council of Hertford in September 672. Michael Lapidge, 'Aldhelm', The Blackwell Encyclopaedia of Anglo-Saxon England, ed. Michael Lapidge, John Blair, Simon Keynes and Donald Scragg (Oxford: Blackwell, 1999), pp. 25-27, (p. 25), has more recently observed that no charter which contains an attestation by Aldhelm as abbot cxists before 680 , though this does not necessarily preclude an earlier date. The earliest exemplars are S71/BCS59 (c.681), and the two scribal charters, S236/BCS61 (c.681), and S237/BCS62 (c.682). But, a letter from Aldhelm to Bishop Wilfrid's abbots, in which he writes with the full authority of a senior churchman, seems to fit the events surrounding Wilfrid's expulsion in 678 (Letter XII, in Lapidge and Herren, Aldhelm: Prose Works, pp. 150-51, 168-70; and for Wilfrid's expulsion, see HE IV.12). It seems likely, therefore, that William was not far off in his assessment of 675 . I would like to thank Duncan Probert for drawing this letter to my attention (pers. comm., 2 December 2002).

Parergon $20.2(2003)$ 
other well. Leuthere and Haedde witnessed one of the charters written by Wimberht (S1164); ${ }^{36}$ Aldhelm witnessed the charter by Haedde (S236), and Haedde witnessed the charter by Aldhelm (S237). In addition, there are another seven charters, admittedly not all of doubtless authenticity, which were attested by, or show as beneficiary, at least two of these clerics. ${ }^{37}$ The scribal attestation format ceased to be used after the early eighth century, perhaps because the practice was not passed on after the deaths of Haedde, Aldhelm and Wimberht. ${ }^{38}$

There are several points which follow from these observations. The use of the scribal attestation - if it is genuine - places the British charter to within a fairly specific time period, namely c.670-725, with the terminus ante quem likely to be earlier. This is well beyond William's date of 601 and underscores the point made earlier that this date must have been erroneously added at some later time. Also, the scribal attestation brings the date of the charter to within the period when Somerset was being subjected by the West Saxons; Somerset was securely in West Saxon hands from the reign of King Centwine (676-685), who gave land to Glastonbury. ${ }^{39}$ This has an impact on the location of the estate of Ineswitrin, a point to be addressed below, as a grant by a British king would not be of land under West Saxon control.

36 Patrick Sims-Williams, 'Continental influences at Bath monastery in the seventh century', Anglo-Saxon England, 4 (1975), 1-10, (p. 5), suggests that Leuthere might have even dictated the wording of this earliest of scribal attestations

${ }_{37}$ S227/BCS25: Haedde, Aldhelm, Leuthere. S234/BCS70, S235/BCS72, S241/ BCS101: Haedde, Aldhelm. S231/BCS63, S243/BCS103 ('dictated' by Wimberht), S1170/BCS71: Haedde, Aldhelm, Wimberht.

Even if some of these were forged, the witness lists would almost certainly have been derived from genuine charters. See Keynes, Atlas of Attestations in Anglo-Saxon Charters, p. 6. In this regard, it is worth adding the witness list of one of the so-called 'Aldhelmian' charters for a grant of land at Malmesbury: Leuthere, Haedde, Wynberht (Wimberht), with Aldhelm as beneficiary. See Lapidge and Herren, Aldhelm: Prose Works, pp. 173-75. It is also probable that Aldhelm's letter to 'Wynberht' was in fact to his fellow scribal attestee (Letter XIII, in Lapidge and Herren, Aldhelm: Prose Works, p. 170). The letter concerned a donation by Baldred to Aldhelm, which could well have been the matter of charter $\mathrm{S1170/}$ BCS71, which also recorded a donation by Baldred to Aldhelm witnessed by Wimberht. The similarity here is striking.

38 The latest charter with such an attestation is from the reign of Ine (688-725): S239/ BCS100, pp. 172-74.

39 Centwine was able to grant land in the region, suggesting that it was securely in his hands. See Malmesbury: S1170/BCS71, pp. 94-97, and Glastonbury: S236/BCS61, pp. 11-15; S237/BCS62, pp. 15-17.

Parergon 20.2 (2003) 
A further implication of the scribal attestation is that its use corroborates the assertion that the format is not British. As has been shown, the scribal attestation was peculiar to a very specific group of West Saxon charters, and used by a very small group of churchmen. It becomes almost certain that the document William was working from could not have been drafted by a British hand. In fact, if the character of the attestations was the primary indicator of its provenance, it could be concluded quite reasonably that it was Saxon in origin. This would be the most expedient explanation, rather than positing alterations to a supposed British original, or suggesting forgery. There are, however, several features of the charter which, if this interpretation is accurate, require further discussion. These are: the location and provenance of the estate of Ineswitrin; the identity of Mauuron and Worgret, and William's assertion that the king making the grant was British.

To begin with the location of the estate and provenance of the name Ineswitrin; it has been assumed that Ineswitrin was the pre-Saxon name for Glastonbury, as William indicates ${ }^{40}$ However, this assertion is unassessable; William in fact offers the earliest documentary record to that effect, closely followed by Caradoc of Llancarfan in his Life of Gildas (c.1140). ${ }^{41}$ Variations on the name Glastonbury, however, do survive from the Anglo-Saxon period: in charters from the reigns of the West Saxon kings Ine (c.704) and Cuthred (c.744),

40 See, for example, Carley, Glastonbury Abbey: Holy House, p. 163.

4) Carley, Chronicle of Glastonbury Abbey, p. 273, n.14. For other references to Ineswitrin in William's work see: AG 1, pp. 44-45; AG 5, pp. 52-53; AG 9, pp. 56-57; AG 69, pp. 140-41; GR I.27-28, pp. 812-13. Caradoc's Life contains the first explication of the derivation witryn $=$ glass, and therefore that Ineswitrin $=$ Glastonbury. Finberg, 'Ynyswitrin', p. 89, incidentally, refers to this reasoning as 'linguistic puerility'. It is possible that William discussed the issue with Caradoc, though William does not include the derivation himself; Caradoc was probably at Glastonbury at the same time or soon after William (Scott, Early History of Glastonbury, p.179, n. 71). Caradoc's explanation was adopted by Gerald of Wales in his De principis instructione 1.20 (c.1193-99), and his Speculum ecclesiae II.8-10 (c.1216). See Gerald of Wales: Journey through Wales, pp. 230-88, and Ceridwen Lloyd-Morgan, 'From Ynys Wydrin to Glasynbri: Glastonbury and the Welsh vernacular tradition', The Archaeology and History of Glastonbury Abbey, ed. Abrams and Carley, 301-15, (pp. 306-07).

Parergon $20.2(2003)$ 
and in the Anglo-Saxon Chronicle. ${ }^{42}$ Given the assertion that Ineswitrin was the British name for Glastonbury, what is perhaps most surprising is that the name appears only rarely in surviving Welsh documentary sources, and then only from as late as the fourteenth and fifteenth centuries. The possibility has consequently been raised that the Welsh form may in fact have been invented to explain the English name. ${ }^{43}$ Therefore, while it can be reasonably claimed that Ineswitrin looks like a British name, it cannot securely be contended that it was the preSaxon name for Glastonbury.

The possibility exists, rather, that Ineswitrin was the name of an estate, as it is in fact called in the charter, that was later erroneously taken to be the early name for Glastonbury, perhaps because the actual origin, identification, and location of the grant was forgotten. Indeed, there are at least two other charters for Glastonbury which indicate that British names could be used in Saxon charters, one of which was the charter that contained a scribal attestation by

42 For Ine: S246/(Glastonbury Cartulary no. 200), p. 26, Glastingaea. For Cuthred: S257/ (Glastonbury Cartulary no. 201), pp. 45-48, Glastingei. The Cartulary was, of course, not compiled till a much later date, c. 1338-40. For the ASC: 688 MS A Glaestinga byrig (marginal entry made c.1001-12); 943 MS F Glaestingeberig. Finberg's assertion, in 'Ynyswitrin', pp. 91-2, that the name Glastonbury derives from the British personal name Glasteing, has been discounted by David E. Thornton, 'Glastonbury and the Glastening', The Archaeology and History of Glastonbury Abbey, ed. Abrams \& Carley, pp. 191-203, who has demonstrated that the association is based on nothing more than a similarity in the names. The popularity of the other name for Glastonbury - Ynys Afallach - appears ultimately to be the responsibility of Geoffrey of Monmouth, but was fairly rare in Welsh vernacular sources (Lloyd-Morgan, 'Ynys Wydrin to Glasynbri', pp. 302-03). William refers to Avallonie in AG 5, pp. 52-53.

43 Lloyd-Morgan, 'Ynys Wydrin to Glasynbri', pp. 306-07, 313. None of the early Weish triads contain any references to Ineswitrin. If, on the other hand, the name is authentic, the tradition can only have been revived in Wales, perhaps from a Glastonbury tradition that also informed William's work, as it does not appear to have enjoyed a continuous history amongst the Britons and their descendants.

Parergon 20.2 (2003) 
Aldhelm. ${ }^{44}$ Hence, the presence of a British name such as Ineswitrin in a charter is not unique, and it does not, in and of itself, have to represent an early name for Glastonbury. Nor for that matter does Ineswitrin even have to be an estate which is located within Somerset. This opens up the possibility of Ineswitrin being situated further west in territory in Devon or Cornwall still under the control of a British king.45

Turning to the identity of the attestees Mauuron and Worgret: in the first instance, purely on onomastic grounds, these personal names have been taken to represent a British connection, particularly given William's reference to their 'barbarous British' nature. ${ }^{46}$ Mauuron, the name of the bishop who makes the scribal attestation, is indeed credibly British. ${ }^{47}$ However, the name Worgret is ambiguous, and while a

4 S237/BCS62, pp. 15-17. Dated to 682, the charter records a grant by King Centwine of three hides to Abbot Haemgils next to a hill 'which is called in the British language Cructan, but among us Crycbeorh' ('qui dicitur Brectannica lingua Cructan, apud nos Crycbeorh'). The second charter, S1249/(Glastonbury Cartulary no. 639), pp. 18-19, insecurely dated to either 677 or 692 , records a donation by Bishop Haedde to Abbot Haemgils of 'three cassati called Lantocal', now Leigh-in-Street near Glastonbury. See also H. P. R. Finberg, The Early Charters of Wessex (Leicester: Leicester University Press, 1964), pp. 109-10. There may be a third West Saxon charter containing a British name, in this instance from King Aethelheard and Queen Frithugyth in 729, recording a grant of a 60 hides at Pouholl to Glastonbury under Abbot Coengils (S253/BCS147, pp. 40-41). Pouholt may derive from the British bo gwelt, 'cattle pasture' (Yorke, Wessex, p. 69). In the lost charter S1680/(Liber terrarum 63), p. 72, King Sigeberht grants 22 hides at Poholt in 756. Charter S248/BCS113, pp. 27-33, also records a grant of land at Pouelt from King Ine, c. 706 , which may be an earlier version of the same name.

45 There is no reason why Glastonbury would not have accepted a grant of land in British Devon or Cornwall, Oliver J. Padel, 'Glastonbury's Cornish connections', The Archaeology and History of Glastonbury Abbey, ed. Abrams and Carley, 245-56, (p. 253), states that Glastonbury 'had no territorial interest in the county of Comwall before the Noman . Conquest, as far as our information goes (emphasis added)'. In saying this, Padel is principally referring to the state of the documentary evidence, rather that claiming that Glastonbury could not have owned land in Cornwall. Thus, the assertion that Ineswitrin may have been in British Devon or Comwall does not contradict Padel's statement. The Ineswitrin charter recording the grant may simply have lost its legal authority, and thus its significance, during the course of time, as various West Saxon kings warred with the kings of Dumnonia.

46 In addition to the chapter under examination, see GR I.28, pp. 812-13. Only the names Mauuron and Worgret will be considered in this paper, and not Lademund, Berthwald and Bregored, due to space restrictions.

47 Oliver J. Padel, personal communication cited in Thomson and Winterbottom, William of Malmesbury Vol. II, p. 405. 
British Celtic derivation is possible, the linguistic origin remains a matter of debate. ${ }^{48}$ It is unfortunate that neither of these churchmen is to be found in any other source. Mauuron, as an identified Briton, could be linked with Dumnonia. However, the record of an abbot called Catwali - a possible British name - ruling an unnamed monastery in Dorset in the final quarter of the seventh century does provide some grounds for uncertainty. ${ }^{49}$ Worgret's abbacy 'of that place' ('eiusdem loci abbas'), taken by William to mean Glastonbury, is also not attested in any other source. Indeed, if he was abbot of Glastonbury, it must have been prior to the abbacy of Haemgils, for whom at least two charters survive from the $680 \mathrm{~s}$, and who appears at the head of what looks to be an abbatial list for Glastonbury, contained in a mid-

48 Carley, Glastonbury Abbey: Holy House, p. 2, is inclined to accept a Germanic derivation. There is, for instance, a Worgret place-name in Dorset, which E. Ekwall, The Concise Oxford Dictionary of English Place-Names, fourth ed. (Oxford: Oxford University Press, 1984), p. 534 , derives from $O E$ weargrod, meaning 'gallows', admittedly an unlikely name for an abbot! Thomson and Winterbottom, William of Malmesbury Vol. II, p. 405, however, state that Worgret could be Celtic; a Welsh subregulus called Wurgeat appears as a witness on two of King Aethelstan's charters dated to 928 and 932 (S400/BCS663; S417/BCS689). These attestations occured during the reign of the Welsh king Hywel Dda (c. 905-50), who was in regular attendance at the court of various English kings including Aethelstan. Hywel himself witnessed several English charters, and even named one of his sons Edwin. See David Kirby, 'Hywel Dda: anglophile?', Welsh History Review, 8 (1976), 1-13. Keynes, Atlas of Attestations in Anglo-Saxon Charters, Table XXXVI, suggests that Wurgeat might have been an Anglicised form of the Welsh Gwriad. H. P. R. Finberg, 'Ynyswitrin', p. 85, also noted the similarity with Wurgeat, and added that the first element Wor- (later Guor-, or Gur-) was common in Old Welsh and Comish names. The name Gorddur is found in Line 1244 of Text B ${ }^{2}$ of $Y$ Gododdin; see John T. Koch and John Carey, The Celtic Heroic Age: Literary Sources for Ancient Celtic Europe and Early Ireland and Wales (Massachusetts: Celtic Studies Publications, 1995), p. 305. Another example might be the name Gunaret, which is found in the later Bodmin manumissions (Whitelock, EHD, no. 144, p. 562).

4. S1164/BCS107, pp. 229-34. The presence of British name elements among the West Saxon royal dynasty means that the significance of the name Catwali is admittedly somewhat ambiguous (Yorke, Wessex, p. 181).

Parergon 20.2 (2003) 
eleventh-century manuscript. ${ }^{50}$ The absence of Worgret from this list is something of a blow to his historicity as abbot of Glastonbury, but the list could well be incomplete. ${ }^{51}$ In any event, if genuine, Worgret's abbacy must have been prior to the $680 \mathrm{~s}$.

The final enigmatic feature of the British charter still to discuss is William's assertion that the donor was the 'king of Dumnonia' ('rex Domnonie'), which he presumably made because that was what he found on the document from which he was working. ${ }^{52}$ This is a fairly explicit statement of the charter's origin. It is noteworthy, however, that William apparently felt the need to elaborate on the extraction of the king, by stating he could be presumed to be British because 'he referred to Glastonbury in his own tongue as Yneswitrin which, as we know, was the British name'. ${ }^{53}$ This statement suggests that William's principal reason for assuming the king was British was that the name Ineswitrin was used in the charter, not that William recognised Dumnonia as a British kingdom. Indeed, William seems to have instead thought that Dumnonia was the old name for

so Charters: S236/BCS61, pp. 11-15, S237/BCS62, pp. 15-17; and possibly S1249/ (Glastonbury Cartulary no. 639), pp. 18-19. S238/(Glastonbury Cartulary no. 979), pp. 23-25, records King Ine's confirmation, c.693, of an earlier grant received by Haemgils. The abbatial list is contained in British Library MS Cotton Tiberius B. v, part l, at 23va (see Foot, 'Glastonbury's early abbots', p. 164). Haemgils seems to have been abbot till c.704, when Berhtwald attests as abbot of Glastonbury in a grant of privileges to the West Saxon churches from King Ine (S245, p. 107-14, from the Malmesbury archives). S248/ BCS113, pp. 27-33, also records a grant of a total of 65 hides of land from King Ine to Abbot Berhtwald in 706. The Liber Terrarum, which lists numerous lost charters of grants to Glastonbury, also records grants made to Haemgils and Berhtwald as abbots of Glastonbury (see Edwards, Early West Saxon Charters, pp. 3-5, 63).

s1 Few English Christian establishments have an uninterrupted record from before the archbishopric of Theodore (669-90). See Nicholas Brooks, 'Anglo-Saxon charters: the work of the last 20 years', Anglo-Saxon England 3 (1974), pp. 211-31, (pp. 216-17); Edwards, Early' West Saxon Charters, p. 48; Foot, 'Glastonbury's early abbots', pp. 168-69, 186.

32 By way of comparison, Gildas in his De excidio Britanniae 28.1, gives the genitive of Dumnonia as 'Damnoniae'. All references to Gildas (hence DEB) will be cited according to chapter and section numbers from Gildas: The Ruin of Britain and Other Documents, ed. and trans. Michael Winterbottom, London: Phillimore \& Co, 1978).

s) AG 35. He provides essentially the same explanation in the GR I.28, pp. 812-13, account.

Parergon 20.2 (2003) 
English Devonshire. ${ }^{54}$ This is interesting in that it tells us something of William's reasoning. However, there does not seem to be any rationale for why the name Dumnonia would have been interpolated into the charter, thus it is probably safe to assume that the king was indeed of that British kingdom.

It is regrettable that because William was unable to decipher the name of the king his floruit and his ethnicity cannot be corroborated. Suggestions made on the basis of the 601 date, in terms of the current examination, are no longer appropriate. ${ }^{5 s}$ H. P. R Finberg offered what was, at the time he was writing, the somewhat venturesome suggestion of Geraint of Dumnonia who was the recipient of a letter from Aldhelm and who fought against Ine of Wessex in $710 .^{56} \mathrm{He}$ reasoned that as this Geraint appears to have also granted land to Sherborne (as outlined below), he may have been attempting to 'conciliate the principal churches of Wessex'. ${ }^{57}$ Given the revised date for the charter, this suggestion bears serious reconsideration.

34 GR 1.100, pp. 146-47: ' ... in Dumnonia, now called Devonshire (Deuenescire) ...'. See also William's GP 11.94, pp. 200-02, 'Crediton is a small villa of Dumnonia, which is commonly called Devonshire'. William's lack of knowledge of Dumnonia is curious, as it is probable that he read Gildas's De excidio Britanniae, in which Dumnonia is included as one of the British kingdoms. See AG 7, pp. 54-55: '... Gildas, neither an unleamed nor an inelegant historian, to whom the Britons are indebted for any fame they have amongst other peoples ...'; and AG 22, pp. 70-71: '... Gildas the wise ...' Also GR I.20.1, pp. 804-05: 'Gildas ... a historian not without style and insight, whom the British have to thank for such knowledge of them as exists among other people .... See also the comment in Thomson and Winterbottom, William of Malmesbury Vol. II. pp. 18, 237.

ss Thomson and Winterbottom, William of Malmesbury Vol. II, p. 405, for example, suggested that the king may have been Geraint map Erbin. This Geraint appears in a later pedigree, probably compiled in the tweifth century, as the grandson of Custennyn, a figure who has been tentatively identified as Gildas's Constantine of Dumnonia (DEB 28.1). See Susan Pearce, The Kingdom of Dumnonia - Studies in History and Tradition in South Western Britain AD 350-1150 (Cornwall: Lodenek Press, 1978), pp. 140-41, and Charles Thomas, Celtic Britain (London: Thames \& Hudson, 1986), p. 67. If Gildas was writing c. 540 as is thought, Geraint map Erbin could have been a reasonable contender; but this hypothesis, of course, rests on the 601 date, which has been shown to be incorrect.

s6 ASC s.a. 710. For Aldhelm's letter to Geraint, see Letter IV in Lapidge and Herren, Aldhelm: Prose Works, pp. 155-60.

37 Finberg, 'Ynyswitrin', p. 88.

Parergon 20.2 (2003) 
The letter from Aldhelm to Geraint - probably written soon after the Council of Hertford convened by Archbishop Theodore in September $672^{58}$ - allows us to assume that Geraint was ruling before the terminus ante quem suggested earlier for the purported abbacy of Worgret (c.680), albeit for a brief period. It also allows us to assume that he was ruling at a time when a British king could have made a grant of land in Somerset (also before c.680), though this is a less crucial point. As has been shown, there is no contemporaneous evidence suggesting that Ineswitrin was the name for Glastonbury, rather than the name of an estate granted to Glastonbury. Finberg made the tentative suggestion that Ineswitrin was Ince in Cornwall, on the Tamar river. ${ }^{59}$ This is a tempting possibility, as Ince is only four miles north-west of Maker, the estate which Geraint granted to the abbey of Sherborne. ${ }^{60}$ Notwithstanding this possibility, the salient observation is that Geraint's floruit corresponds with the dates indicated by the scribal attestation.

58 Lapidge and Herren, Aldhelm: Prose Works, pp. 9, 140-43. The letter survives only in the eighth-century MS Codex Vindobonensis 751. If William had read Aldhelm's letter he may have expressed more certainty regarding the king in question: in the letter, Dumnonia is clearly identified as being ruled by a British king. William was aware of the letter's existence, but complained that it was lost, destroyed by the Britons (GP V.196, pp. 34344; V.215, pp. 359-61). For the Council of Hertford, see HE IV.5.

59 Finberg, 'Ynyswitrin', p. 93, asserted that Ince is cognate with ynys. He added (ibid.pp. 93-94, and in 'Sherborne, Glastonbury and the expansion of Wessex', in his, Lucerna, 95-115, (pp. 101-02) that ynys or Ince would have been rendered ig or ieg in Old English, and drew attention to the concordance with the name of an estate called Lin-ig (or Liuig), apparently near the Tamar ('iuxta Tamer'), given to Glastonbury by King Ine. This identification derives from William, AG 69, pp. 140-41. Padel, 'Glastonbury's Comish connections', pp. 250-52, as well as considering the linguistic reasons why this identification is inappropriate, notes that the context of the Linig grant is better identified with a collection of grants from Ine listed in the charter S248/BCS113, pp. 27-33. In this clarter, the location of the grants is given as 'iuxta flumen quod appellatur Tan', rather than 'iuxta Tamer'; in other words, beside the River Tone in Somerset. As a location for Linig, this makes better historical sense. The river Tamer in William's De antiguitate Glastonie, thus, seems to be an error for the river Tan (the editor, John Scott, actually translates the Tamer in the MS as Tone, assuming that this is what William meant, though he provides no explanation). Finberg was, perhaps, drawing an overly long bow here.

6o This grant is recorded in a late-fourteenth-century list of royal benefactors of Sherbome and the lands they granted - British Library MS Cotton Faustina A.ii - though it appears to have been copied from an earlier list probably compiled some time after 1035 , the date of the latest grant mentioned (Edwards, Early West Saxon Charters, pp. 243-49). The grant is recorded thus: 'Gerontius rex dedit Macuir de v hidis iuxta Thamar'.

Parergon 20.2 (2003) 
To speculate further on the provenance of the charter: the letter from Aldhelm, and the later donation to Sherborne where Aldhelm became bishop, means that Geraint was in contact with a Saxon clergyman, and indeed, there is evidence that Aldhelm travelled into Cornwall on at least one occasion. ${ }^{61}$ What is most significant is that Aldhelm, as noted, was the scribe of one of the two Glastonbury charters that have a scribal attestation, and a witness to the other ${ }^{62}$ Further, as has also been noted, the charter for which Aldhelm was scribe records a British name for an estate. ${ }^{63}$ Thus, Aldhelm was familiar with and used the scribal attestation format, and had himself recorded a British estate name in a charter. It is, therefore, offered here as a hypothesis that Aldhelm was the agent for the grant of Ineswitrin, having mediated a donation by Geraint to the Saxon monastery at Glastonbury. Aldhelm then either drafted the charter for Mauuron - probably one of Geraint's bishops - to complete, or tutored him in a format that would be acceptable for a Saxon house. This would account for the early West Saxon character of the charter as well as the British personal name Mauuron, and the British place-name Ineswitrin.

Clearly, this hypothesis regarding the provenance of, and Aldhelm's role in, the Ineswitrin grant would be more robust if he had also appeared as an attestee. However, Aldhelm's name may not have appeared on the original if he was the drafter of the charter for Mauuron. Alternately, William may not have included it in the De antiquitate Glastonie; he was known to have shortened witness lists. ${ }^{4}$ What the hypothesis does imply, if it is accurate, is that the so-called British charter does not require the presumption of a pre-Saxon foundation for Glastonbury, and cannot be taken as evidence that a pre-Saxon British community

61 Aldhelm, in his Carmen Rhythmicum, tells us, 'when I set out for nasty Dumnonia [usque ... Domnoniam] and was proceeding through Cornwall [per ... Comubiam] ...'. See Michnel Lapidge and James L. Rosier, Aldhelm: The Poetic Works (Cambridge: D.S. Brewer, 1985), pp. 171-80. On the relationship between Aldhelm and Geraint, see Martin Grimmer, 'Saxon bishop and Celtic king: interactions between Aldhelm of Wessex and Geraint of Dumnonia', The Heroic Age, 4 (2001), http://member.aol.com/heroicagel/ homepage.html

62 That is, S237/BCS62, and S236/BCS61, respectively.

63 Namely, Cructan for Crycbeorh recorded in S237/BCS62.

4t Compare, for example, S245/BCS108, pp. 107-14, with AG 40, pp. 92-95. The cartulary version contains the names of eleven clerical witnesses, in addition to lay witnesses, whereas William's version of the witness list is rendered simply as ' $\mathrm{I}$, Aldhelm, have subscribed; et cetera'. On this point, see Yorke, Wessex, p. 55. 
metamorphosed into a Saxon one. ${ }^{65}$ Yet, the interpretation offered does suggest there was some degree of amicable interaction between the Britons of Dumnonia and the West Saxon church. It might have been that Glastonbury was established near the then border with Dumnonia, and Geraint was moved by political wariness to recognise the Saxon community. ${ }^{66}$ Indeed, the fact that Geraint was at war with Ine in 710, the year after Aldhelm's death, suggests that Aldhelm could well have been involved in negotiating some manner of accord between the West Saxons and the Dumnonians, or at the very least was able to persuade Ine and Geraint to avoid outright hostility. ${ }^{67}$ Alternately, Geraint may have been impressed by the dynamism of the re-invigorated Roman church of the West Saxons under Bishop Leuthere, and ultimately Archbishop Theodore. In this vein, it might have been Aldhelm who persuaded Geraint to make this donation, as well as the one to Sherborne.

The hypothesis offered in this paper is that the so-called 'British charter' in 'William of Malmesbury's De antiquitate Glastonie may in fact be West Saxon in origin, and may represent an authentic record of a donation from Geraint of Dumnonia in the 670 s to the Saxon monastery of Glastonbury. It is possible, of

65 This is actually corroborative of the archaeological evidence at the abbey site. According to Phillip Rahtz, 'Pagans and Christians by the Severn Sea', The Archaeology and History of Glastonbury Abbey, eds. Abrams \& Carley, pp. 3-37, (p. 33), there is no archaeological evidence to indicate that the Glastonbury abbey site was established before the late seventh or early eighth centuries, though excavation has only been on a very small scale. See also Phillip Rahtz, 'Glastonbury Abbey', Blackwell Encyclopaedia of Anglo-Saxon England, ed. Lapidge et al, pp. 206-07, and Christopher A. Snyder, An Age of Tyrants: Britain and the Britons A.D. 400-600 (Pennsylvania: Pennsylvania State University Press, 1998), pp. 178-79. This is not to say that there was never a British community in the vicinity. The Tor, for example, shows ample evidence of sub-Roman occupation, albeit subject to uncertain interpretation as to whether it was a secular or a monastic community. See Phillip Rahtz, 'Glastonbury Tor', The Quest for Arthur's Britain, ed. Geoffrey Ashe, (London: Pall Mall Press, 1968), pp. 139-153, and Rahtz, 'Pagans and Christians', pp. 32-33. A later monastic settlement on the Tor, and the nearby Beckery Chapel site, do not display any archaeological evidence earlier than the late Saxon period, and appear to represent daughter houses of the by then well-established Saxon abbey (Rahtz, 'Glastonbury Abbey', p. 207). There is no evidence to support the presumption that the Tor community 'moved' to the abbey site, as claimed by Hase, 'The church in the Wessex heartlands', p. 50.

o6 As Finberg, 'Ynyswitrin', p. 88, implied.

67 ASC s.a. Prior to 710, the most recent record of warfare between the West Saxons and Britons in the ASC is the non-specific entry s.a. 682 , which states that Centwine 'put the Britons to flight as far as the sea'. 
course, that the charters with scribal attestations in the Glastonbury archive could have provided a model for a later forger, and that this accounts for the existence of the scribal attestation contained in the Ineswitrin grant. However, the circumstances enumerated in this paper, and the peculiarly early Anglo-Saxon features of the charter, at least allow that the hypothesis is worthy of consideration. Therefore, while the 'British charter' cannot stand as evidence for a British community resident at Glastonbury before the Saxon foundation, it is nonetheless significant in terms of what it implies about relations between the West Saxon church and the kingdom of Dumnonia. There may not have been any continuity between Romano-British and West Saxon Christian communities at Glastonbury, ${ }^{68}$ but there still appears to have been interaction across the frontier.

School of History and Classics University of Tasmania

68 Costen, Origins of Somerset, pp. 77-78.

Parergon 20.2 (2003) 